\title{
Skepticism in Hume's Politics and Histories
}

\section{El escepticismo en el pensamiento político e histórico de David Hume}

\author{
Peter S. Fos $1^{1}$ \\ Transylvania University (Estados Unidos)
}

Recibido: 06-03-18

Aprobado: 19-04-18

\begin{abstract}
This essay argues that Hume's political and historical thought is well read as skeptical and skeptical in a way that roots it deeply in the Hellenistic traditions of both Pyrrhonian and Academical thought. It deploys skeptical instruments to undermine political rationalism as well as theologically and metaphysically political ideologies. (1) Hume's is politics of opinion (doxa) and (2) appearance (phainomena). It labors to oppose faction and enthusiasm and generate (3) suspension (epochê), (4) balance (isosthenia), (5) tranquility (ataraxia), and (6) moderation (metriopatheia, moderatio). Because Hume advocate the use of reflectively generated but epistemically and metaphysically suspensive general rules, his political thought is not intrinsically conservative. While it valorizes stability and peace, Humean politics accepts a contested and open-ended (zetesis) political order, one that requires continuous maintenance and revision but does not pretend to any ultimate or final progress or end.
\end{abstract}

Key-words: David Hume, skepticism, scepticism, Pyrrhonism, Academicism, political theory, early modern philosophy.

\footnotetext{
${ }^{1}$ (pfosl@transy.edu). Peter S. Fosl is Professor of Philosophy and chair of the PPE program at Transylvania University in Lexington, Kentucky. Fosl is author of numerous articles on Hume, skepticism, and the history of philosophy. He was the David Hume Fellow at the Institute for Advanced Studies in the Humanities at the University of Edinburgh (2013-14). Fosl is co-author with Julian Baggini of The Philosopher's Toolkit and Ethics Toolkit and co-editor of The Dictionary of Biography volumes on British Philosophy. www.PeterFosl.com.
} 


\section{Resumen}

Este ensayo pretende demostrar que el pensamiento político e histórico de Hume se interpreta bien cuando se lo lee como escéptico, y de un escepticismo que hunde sus raíces en las tradiciones helenísticas tanto del pensamiento académico como del pirrónico. Despliega instrumentos escépticos que socavan tanto el racionalismo político como las ideologías políticas de base metafísica o teológica. (1) La de Hume es una política de la opinión (doxa) y (2) la apariencia (phainomena). Trabaja para oponerse a la facción y al entusiasmo y generar (3) suspensión (epochê), (4) balance (isosthenia), (5) tranquilidad (ataraxia), y (6) moderación (metriopatheia, moderatio). A causa de la defensa de Hume del uso de reglas generales producidas de forma reflexiva, pero que suspenden compromisos epistémicos o metafísicos, su pensamiento político no es intrínsecamente conservador. Mientras que valora la estabilidad y la paz, la política humeana acepta un orden político de confrontación abierta (zetesis), un orden que requiere de un mantenimiento continuo y de revisiones, pero que no pretende un progreso o fin último o definitivo.

Palabras-clave: David Hume, escepticismo, Pirronismo, Academicismo, teoría política, filosofía moderna.

In this essay, I wish to argue that Hume's political and historical thought is well read as skeptical and skeptical in a way that roots it deeply in the Hellenistic traditions of both Pyrrhonian and Academical thought. The very idea that Hume's philosophical and political thought is connected is itself not uncontroversial. T. H. Grose saw in Hume a decisive turn away from philosophy when Hume began writing essays and history. ${ }^{2}$ Neil McArthur runs to the negative evidence of Hume's text when he observes that "there is not a single passage where" Hume "explicitly extends his scepticism to the realm of politics." 3 Andrew Sabl argues that while Hume may be a skeptic in philosophy, he is an empirical scientist in matters of politics and history: "Hume's political writings," Sabl writes, "and above all his History, are empirical enquiries modeled at least loosely on modern science." has argued that skepticism, including Hume's, has itself properly no political import whatsoever, and that politics only seeps into skepticism at the limits of doubt. ${ }^{5}$ I wish to argue in this section that these thinkers are mistaken and that Hume's historical and political thought shows not only how deeply connected it is to his own idiosyncratic skeptical philosophy but also describes the contours

\footnotetext{
${ }^{2}$ Grose (1889), 3.75-76; cited by McCormick (2013), 77.

3 McArthur (2007), 117.

${ }^{4}$ Sabl (2015), 149; Cf. Sabl (2012).

${ }^{5}$ Lom (2010).
} 
of skeptical philosophy more generally. It should not be surprising that this is so if one considers proper what James Harris recommends, namely that we read Hume's "History not as an exercise in belles lettres that Hume turned to once his most important work was done, but, instead, as the culmination and crowning glory of Hume's career as a philosophical analyst of the age in which he lived."6

The idea that Hume advances a skeptical politics, of course, is not entirely new. Duncan Forbes in his monumental Hume's Philosophical Politics (1975), writes about Hume as a "sceptical Whig."7 In this, Forbes draws from Hume's remark in a 9 February 1748 letter to his cousin, Henry Home (Lord Kames), the same year he would publish the first Enquiry. There Hume says in the context of a discussion of the Protestant Succession that he is "a Whig, but a very sceptical one." ${ }^{8}$ Forbes, however, calls Hume not only a skeptical but also a "scientific" Whig, a characterization he had previously made of Adam Smith and John Millar, because, in contrast to "vulgar" Whigs, Hume is "cosmopolitan" and supports the parliamentary mixed monarchy then thought to be modern in British politics - and also, of course, because Hume develops a general political theory or science. ${ }^{9}$ Hume is a "sceptical Whig" for Forbes moreover because Hume rejects what Forbes, in an allusion to Bacon, calls Whiggism's parochial ideological "idols" — namely the idea that all monarchial systems are illegitimate, that the Stuart monarchs were uniformly wicked, that there was no liberty under the French monarchs, and that political obligation can only be grounded in consent of the governed of the sort described by social contract theory. ${ }^{10}$

Eugene F. Miller in 1985 interpreted Hume's political writing in the Essays as an extension into common life of his abstract philosophical theories, a line of continuity he shares with Donald W. Livingston. ${ }^{11}$ With Marie Martin, Livingston argues in their collection for the general vision of Hume as a philosopher of culture, politics, and history rather than merely epistemology and science. ${ }^{12}$ More recently, James Wiley has argued that "rather than being something Hume takes up after abandoning serious philosophy, humanist and literary concerns" - which for Wiley include political concerns - these "derive from Hume's 'skeptical' philosophy."13 John Christian Laursen has argued that

${ }^{6}$ Harris (2007), 336.

${ }^{7}$ Forbes (1975), 139-40, 299.

8 Hume, Letters (1932); 1:111, \#62; hereafter "LT."

${ }^{9}$ Forbes (1975), 140; Forbes (1954); Forbes (1978).

${ }^{10}$ Forbes (1975), 299.

${ }^{11}$ Miller's introduction to Hume's Essays (1985), xviii; cited by McCormick (2013), 78. Especially Livingston (1998).

12 Livingston \& Martin (1991).

13 Wiley (2012), 16. In Wiley's reading, Hume's skepticism largely serves a negative function, clearing out metaphysics and religion to make room for what he calls a humanistic practice. In my reading, Hume's skepticism, of course, is congruent with his humanism. His speculative anatomy, that 
Hume's philosophy of custom and habit, especially in his focuses on opinion and politeness/manners, defines the skeptical dimensions of his politics. ${ }^{14}$ Miriam Schleifer McCormick has agreed that "there is a unity between Hume's philosophical reflection and his political views..." and that "the conclusions Hume reaches in his political writings are natural outgrowths of his skepticism" - not unlike the way for Hume one kind of mitigated Academical skepticism may be thought of as the "natural" outgrowth of Pyrrhonian doubt. ${ }^{15}$ McCormick argues, like Forbes, that Hume's political skepticism is evident in his critiques of theories of (i) political legitimacy and (ii) obligation, but she also stresses (iii) his moderation, (iv) his acceptance of limited inquiry, and (v) his opposition to faction, as well as (vi) his support for American independence. As a skeptic, she writes, Hume holds that "our most basic beliefs" about politics, every bit as much as about natural science, "are grounded in principles that lack rational foundation and that abstract reasoning can lead us to the brink of total skepticism," that is, to the brink of a skeptical crisis of the sort he describes in the 1739 A Treatise of Human Nature. ${ }^{16}$

Ryu Susato has argued that Hume's social-political-cultural outlook manifests a much broader "spirit of scepticism" that can be more precisely described by four characteristics: (i) Hume's empirical naturalism, especially his anti-rationalist theory of association and opinion, which focuses on contingencies and diversity in both the social-political and natural orders; (ii) Hume's "scepticism about the clear demarcation of various issues," such as the limits of legislative power; (iii) his acceptance of the instability of opinion across politics and natural science such that "Hume naturally cannot uphold the attainability of eternal truth by reason; much less the perfectibility of human nature"; and (iv) Hume's dialogical and ironic literary styles. ${ }^{17}$ Susato also connects Hume's social political thought to skepticism through (v) his criticism of religion and his implicitly anti-religious naturalistic secularism.

It is true that Hume sounds a defensive note, distancing his History from skepticism (though perhaps he dissimulates) when he writes to John Clephane on 1 September 1754 that: "I composed [the History of Great Britain] ad populum, as well as ad clerum, and thought, that scepticism was not in its place in an historical production" (LT 1.189, \#93). Others, however, among Hume's epistolary remarks take on a different valence. In addition to Hume's 1748 skeptical self-description in his letter to Kames, Susato locates a remark in a

is, informs his moral or humane painting: "An anatomist, however, is admirably fitted to give advice to a painter; and 'tis even impracticable to excel in the latter art, without the assistance of the former" (T 3.3.6.6, SBN 620-621). Harris suggests Alexander Pope's An Essay on Man (1733-34) may have had some influence on Hume's project as an anatomist; Harris (2015) 82.

${ }^{14}$ Laursen (2011b), 90ff., 94ff.

${ }_{15}$ McCormick (2013), 78. Hume (2000), 12.3.25, SBN 162; hereafter, "E."

${ }^{16}$ Hume (2007), 1.4.7; hereafter, "T."

${ }^{17}$ Susato (2015), 12, 17-20.

Araucaria. Revista Iberoamericana de Filosofía, Política, Humanidades y Relaciones Internacionales, año 20, $\mathrm{n}^{\circ} 40$ Segundo semestre de 2018. Pp. 371-401. ISSN 1575-6823 e-ISSN 2340-2199 doi: 10.12795/araucaria.2018.i40.17 
12 September 1754 letter to the Abbé le Blanc, notably the French translator of Hume's Political Discourses, that seems suggestive: "The philosophical Spirit, which I have so much indulg'd in all my Writings, finds here" in the History of Great Britain, "ample Materials to work upon" (LT 1.193, \#94). ${ }^{18}$ If Hume's philosophical spirit is indeed skeptical, and if that spirit pervades "all" his writings, then arguably he implies here that his History and political works are skeptical, too. Indeed, Hume includes history and political thought among those "subjects" he identifies as "... best adapted to the narrow capacity of human understanding" and "common life" (E 12.3.24-25). Importantly, he offers that catalog of subjects best adapted to the understanding and common life at the end of the first Enquiry just after characterizing himself as an Academic skeptic, writing that:

Moral reasonings are either concerning particular or general facts. All deliberations in life regard the former; as also all disquisitions in history, chronology, geography, and astronomy.

The sciences, which treat of general facts, are politics, natural philosophy ... $\& c$. where the qualities, causes, and effects of a whole species of objects are enquired into. (E 12.3.30-31)

Early on in Hume's Dialogues concerning Natural Religion (1779), politics is also collected along with natural science among investigations performed within the realm of common life: "So long as we confine our speculations to trade, or morals, or politics, or criticism, we make appeals, every moment, to common sense and experience, which strengthen our philosophical conclusions." 19 History and politics, in short, properly conceived, lie within the realm of inquiry permitted by Humean skepticism.

All this is right in Wiley, Laursen, Schleifer McCormick, Susato, et alia, but there is more. Scholarly interpretation continues to evolve, as Sabl, for example, has more recently modified his view to argue that Hume's skepticism is evident in his social-political essays and his historical writing, though only in their formal and rhetorical qualities. Sabl now maintains at least "that skepticism is very helpful for understanding not the content of Hume's political work but its form, its style, and its intended effect" - a style that Thomas Poole also recognizes as "sceptical" and "urbane." ${ }^{20}$ Even McArthur concedes that at T 1.4.7.12 (SBN 270-71) Hume-just as he is emerging from his moment of skeptical crisis - at least points to a connection between his philosophical thinking and political matters when he observes that:

\footnotetext{
18 Susato (2015), 13 .

${ }^{19}$ Hume (1947), 1.10; hereafter "D."

${ }^{20}$ Sabl (2015), 150. Poole (2015), 112.
} 
I cannot forbear having a curiosity to be acquainted with the principles of moral good and evil, the nature and foundation of government, and the causes of those several passions and inclinations, which actuate and govern me.... I feel an ambition to arise in me of contributing to the instruction of mankind.... ${ }^{21}$

But the way Hume's politics have been described as skeptical has been insufficient to its task, not only because more attention is warranted to the content of Hume's social-political thought but also and more particularly because of the inadequate way Hume's thought has been situated in the skeptical traditions.

I wish to change that here by offering a more extensive account of Hume's political skepticism that places him more deeply in skeptical philosophy. In particular, in what remains of this essay, I wish (1) to describe how Hume's political thought conforms to both Pyrrhonian and Academical skepticism, and I wish to use those findings to resolve a number of persistent interpretive puzzles, as well as to explicate what for Hume composes a distinctively skeptical political philosophy per se. In particular, I wish to address (2) the extent to which it is proper to read Hume as a conservative or a more progressive thinker. I wish to explain in addition how (3) Hume resolves the skeptical apraxia problem in political terms so that he can not only make normative prescriptions about political conduct, even political resistance, but also develop (4) a prescriptive political science. Hume does so through what I will described as a philosophy of "critical habits and customs."

\section{How Can Politics Be Skeptical at All?}

Thomas Merrill reads Hume's skeptical turn to politics by analogy with the Socratic turn to the human and the political from the natural philosophy of the pre-Socratics. ${ }^{22}$ Exceeding Sabl's recognition of Pyrrhonian form, Merrill writes that Hume's work on politics and history:

... does partake of classic skeptical styles and methods. It is in Hume's Essays and History that we find the reporter of all sides, the doubter of exclusive claims, the distruster of systems, the person determined to find some possible truth in a variety of viewpoints and exclusive and absolute truth in none. We also find, to

\footnotetext{
${ }^{21}$ McArthur (2007), 5; cited by Susato (2015), 12.

${ }^{22}$ Merrill (2015a), Chapter 1, "Hume's Socratism"; cf. Merrill (2015b). Merrill writes that he uses Hume's "Socratic reference" (T Intro. 7, SBN xvi-xvii) connecting him to Socrates's turn from pre-Socratic natural philosophy to social-political topics "as a means of thinking about Hume's skepticism." Merrill claims "that Hume's 'science of human nature' is a political science that attempts to understand moral and political opinion from the inside" of common life. Merrill is alive to this Socratic dimension of Hume's thought but not to the way it connects it to Pyrrhonian skepticism and the Pyrrhonian Fourfold. Merrill, however, is not hostile to a skeptical reading of politics, Socratism is in many ways skeptical. For Merrill while there maybe, provisional progress, there remains background aporia; Merrill (2015b), 25. I am grateful for Merrill's comments on this material.
} 
a surprising degree, someone who both aspired to and hoped to evoke in others the Pyrrhonian elements that have precisely been noted as absent in Hume's Treatise: suspension of judgment (epoché) and tranquility (ataraxia). ${ }^{23}$

Let us examine Hume's use of "skeptical styles and methods" more closely and more extensively as well as what else of skepticism Hume "hoped" to "evoke."

\subsection{The Politics of Doxa}

It is on the issue of the limits of knowledge in politics possible for humans that F. A. Hayek connects Hume's skepticism to his political theory. ${ }^{24}$ And, indeed, skepticism centers on doxa (opinion) rather than epistemê (knowledge). Like skeptical Humean science, Hume analyzes politics skeptically as a form of doxa and criticizes it when it is dogmatic. ${ }^{25}$ In his 1741 essay, "Of the First Principles of Government," an essay that appears on the heels of the 1739-40 Treatise, Hume writes that it "is therefore, on opinion only that government is founded." 26 Moreover, while considerations of "interest" figure prominently in Hume's analyses of social-political matters - e.g. in the genesis of rules of justice-Hume is clear that by "interest" he means people's opinions of their interest: "though men be much governed by interest; yet even interest itself, and all human affairs, are entirely governed by opinion" (ES 51). Hume's analysis of the bounds of legislative authority is typical when he observes that making that demarcation "is the work more of imagination and passion than of reason" (T 3.2.10.14; SBN 560-61). ${ }^{27}$ Moreover, as Susato rightly concludes, Hume's acknowledgement of the contingency, variability, and indeterminacy of opinion "is central to his system of 'the science of MAN' and his Sceptical Enlightenment." 28 Politics is for Hume doxa all the way down.

23 Sabl (2015), 151 .

24 Hayek (1966), 342: Hume's political ideas “are most intimately connected with his general philosophical conceptions, especially with his sceptical views on the "narrow bounds of human understanding',."

25 Marie Martin finds in Hume's repudiation of knowledge as basic to moral life to be what distinguishes him from the stoics; Martin (1994), 328-29; Wulf (2000), 98, discusses Martin and reads implications into this difference for a skeptical politics without appeal to knowledge.

${ }^{26}$ Hume (1985), 32; hereafter, "ES." Susato has it precisely backwards, then, when he reads Hume as transforming "doxa" so that it can be used in dogmatic political science. Susato writes: "For Hume, to recognize the central role of opinion in our everyday social and political life it was necessary to depart from the traditional (negative) connotations of the word 'opinion' as doxa, which should be eradicated or suppressed to read the truth"; Susato (2015), 70. Rather, I wish to argue, Hume's use of doxa is part of his transforming political science in a skeptical way so that it suspends judgment on questions of ultimate truth. Susato follows C. B. Macpherson in suspecting the source of Hume's view about government being rooted in opinion to be William Temple's "An Essay upon the Original and Nature of Government" (1679), along with Hobbes, Locke, Bayle, and Shaftesbury; Macpherson, indeed, describes Temple as "the Hume of the seventeenth century"; Susato (2015), $60 \mathrm{ff}$.

27 Susato (2015), 69.

28 Susato (2015), 72.

Araucaria. Revista Iberoamericana de Filosofia, Politica, Humanidades y Relaciones Internacionales, año 20, ${ }^{\circ} 40$. Segundo semestre de 2018. Pp. 371-401. ISSN 1575-6823 e-ISSN 2340-2199 doi: 10.12795/araucaria.2018.i40.17 


\subsection{Pyrrhonian Politics, Revolution, and Cartesianism}

In addition to being a matter of doxa, Hume's political thinking is ephectic, that is suspensive, and non-apprehensive in that Hume refuses any metaphysical grounding to the political order. ${ }^{29}$ Just as Hume skeptically refuses metaphysics and ultimate rational justification for belief, scientific and otherwise, he refuses rational and metaphysical grounding for government and society. That includes for Hume grounding the political in a divine origin (apprehended by revelation or otherwise), natural law (especially a natural law grounded in divine law), natural rights (endowed in people by a creator or otherwise), and the false philosophical fictions of an original contract or an ancient constitution. In Hume's February 1748 letter to Kames, he not only declares that he is a skeptical Whig. After acknowledging his understanding of the social and political punishment he faces as a skeptic about the Protestant Succession, he also confesses his having epistemically apprehended nothing about it and perhaps nothing regarding politics and other matters at all: "Some people would frighten me with the consequences that may attend this candour, considering my present station, but I own I cannot apprehend anything" (LT $1.111, \# 62)$.

So much is especially clear in Hume's refusing what might be called metaphysical politics. In political thinking, just as in natural science and metaphysics, Hume resists philosophical posits not grounded in experience or common life that would pretend to legitimate authority and obligation in an $a$ priori and summarily universal way. He also rejects a conception of reasoning capable of establishing autonomously and independently political authority and legitimacy.

In a memorable and trenchant phrase, Livingston describes one of the principal kinds of political thinking Hume opposes, "political Cartesianism," a species of political theorizing that pretends to operate from something like what Thomas Nagel has called a "view from nowhere"-a commanding, detached position that speciously claims to have transcended the "gross earthy mixture" (T 1.4.7.14, SBN 272) of "common life." ${ }^{30}$ In Pyrrhonian terms, political Cartesianism marks the philosophical pretense of operating beyond the "Fourfold" of appearances (phainomena) and common life (bios, ho bios ho koinos) - nature, the passions, custom, and technai. ${ }^{31}$ This "false" and pathological species of political philosophy postures as if it were characterized

\footnotetext{
${ }^{29}$ About epochê see Cicero's Academica (ACD 1.12.45) and Sextus Empiricus's Outlines of Pyrrhonism (PH 1.3.7). About non-apprehension, see PH 1.1.3-4.

${ }^{30}$ Livingston (1984), Chapter 12; and see especially "Cartesianism in Politics," 275-78. Nagel (1986); Nagel plays off Spinoza's recommendation to regard the world "sub specie aeternitatis," under the aspect of eternity (Ethics II, prop. 44).

${ }^{31}$ Sextus Empiricus (1976), 1.11.23, 1.11.21, 1.34.237; hereafter, "PH."
} 
by absolute (i) autonomy and independence from history, culture, opinion, and nature. It moreover makes claim to its own overriding (ii) authority so that it is warranted in pronouncing judgments upon common life in particular and in toto: "False philosophy has many forms ranging from religious superstition to metaphysics, but they are all cases of seeking, by way of the autonomy principle, some Archimedean point outside the prejudices and customs of common life from which the order as a whole can be judged." 32 This "false" kind of thinking is Cartesian in Livingston's view, since it is closely connected to Descartes's announced aspiration to "deconstruct" the whole of his past beliefs (scientific, ordinary, moral, etc.) in favor of what his detached, autonomous, and solitary cogito-with its self-generated, self-verifying method-would authorize and establish.

Livingston rightly understands that Descartes's gesture is more than epistemically self-deluding. False philosophy and religion are politically dangerous, as well. Because they authorize through their mad "philosophical melancholy and delirium" (T 1.4.7.9, SBN 269) radical and totalized judgments, they legitimize the most extreme forms of conduct-conduct contrary to common practices, as well as a purportedly "total" kind of revolution. They warrant, that is, aspirations to the wholesale overturning of the beliefs and practices of custom and history in favor of the ideal "plans of imaginary republics" spun from free-floating philosophical reason-as if doing so were possible: "Harrington's Oceana was well adapted to that age, when the plans of imaginary republics were daily subjects of debate and conversation.... The idea, however, of a perfect and immortal commonwealth will always be found as chimerical as that of a perfect and immortal man." 33 About totalized and extreme political projects, Hume is deeply skeptical. There is something like Albert Camus's thinking in Hume's resistance to abstruse political theory and ideology - a resistance to the murderous ideologies Camus condemns in the L'homme révolté (1951) and in "Ni Victimes, ni bourreaux" (1946), as well as those who subscribe to them with "absolute certainty." Abstruse ideology is itself dangerous, and its malignancies are precisely the sort that skepticism practiced politically aims to remedy.

\subsection{Political Isosthenia, Ataraxia, and Moderatio}

Roger Eichorn has rightly argued that Pyrrhonism properly leads to "a healthy degree of moderation" in politics, and in line with this assessment Hume advances in opposition to the political effects of false philosophy and religion both ataraxia (tranquility and peace, $\mathrm{PH} 1.12 .25$ ) and metriopatheia

\footnotetext{
${ }^{32}$ Livingston (1984), 6.

33 Hume (1983), 6.62.153; hereafter "H."
}

Araucaria. Revista Iberoamericana de Filosofia, Politica, Humanidades y Relaciones Internacionales, año 20, $\mathrm{n}^{\circ} 40$. Segundo semestre de 2018. Pp. 371-401. ISSN 1575-6823 e-ISSN 2340-2199 doi: 10.12795/araucaria.2018.i40.17 
or moderatio (moderate emotion). ${ }^{34}$ Epoche is itself a kind of stillness, and the resulting ataraxia is a serenity of soul Sextus compares to the stillness of the sea (galene), a metaphor that connects back to Hume's important and well-known self-description of his faculties as a "leaky weather-beaten vessel" (T 1.4.7.1, SBN 263). Sextus writes: "Suspense' [epochê] is a state of mental rest [stasis dianoias] owing to which we neither deny nor affirm anything. 'Quietude' [ataraxia] is an untroubled and tranquil [galenotes] condition of soul" (PH 1.4.10). In cases where some disturbance is "unavoidable," "moderate passion" or emotion (metriopatheia, in Latin moderatio) will do (PH 1.12.25), for Pyrrhonians as well as Academics. ${ }^{35}$

In the Treatise, Hume makes a plea for the ataractic submission to customary government against philosophical inquiries into the origins of a polity that would threaten to undermine its legitimacy: "No maxim is more conformable, both to prudence and morals, than to submit quietly to the government, which we find establish'd in the country where we happen to live, without enquiring too curiously into its origin and first establishment. Few governments will bear being examin'd so rigorously" (T 3.2.10.7, SBN 558). Baxter rightly connects the dots with Academic skepticism in Hume and stability in epistemological matters, but it is so in for Hume's political theory, as well. Baxter writes: "Precedence for seeking stability is found in Sextus's discussion of the preference of the New Academy for 'appearances which are plausible and scrutinized and undistractable,' or, as [Benson] Mates translates it, "the phantasia that is plausible, tested, and stable" (PH 1.33.229, M 7.242-43). ${ }^{36}$

A reluctance simply to undermine is typical in Hume for reasons of Pyrrhonian isosthenia, too. Just as he does in the Dialogues concerning Natural Religion, in his histories and essays Hume is often at pains to balance the various sides of an issue and to do so charitably. Sabl is right that like Sextus, Bayle, and other Academics, Hume commonly if not universally writes as a reporter of the various sides of an issue rather than as a advocate for a specific side. His objective is not only to dissimulate, as he likely does sometimes, but also to sympathize with the various parties and to present their ideas contextually even if critically. ${ }^{37}$ Hume's aim is not only to achieve what isosthenia (PH 1.22.196) or balancing is possible but also to reveal the logical vulnerabilities of competing positions in a way that diffuses the powerful emotions those positions potentially generate. John Immerwahr suggests that Hume develops

${ }^{34}$ Eichorn (2014), 142-43. Quoted by Laursen (2016), 19. Wulf argues that caution as a political principle, especially for political advisers, is also characteristic of Hume's moderate skepticism; Wulf (2000), 86ff. 89ff. For a reading of Hume as a cautious and conservative skeptic, see Letwin (1965).

35 See Immerwahr (1992) on Hume's various strategies to tranquilize the passions.

${ }^{36}$ Baxter (2008), 101n16. See Mates (1996). On the Academics and what they find plausible or pithane, see: Sextus Empiricus, Adversus mathematicos, M 7.242-43. Cited conventionally as "M."

37 See Herdt (1997) on this kind of critical sympathy. 
a strategy for tranquilizing politics by what he calls "moderation through opposition," diffusing "passion with passion," as it were via a kind of political isosthenia. ${ }^{38}$ Hume does so with religions, too. ${ }^{39}$ Hume labors along these lines towards the Pyrrhonian telos of peace and social concourse, just the sort of safe disagreement the theological opponents Philo and Cleanthes are able to reach in Part 12 of the Dialogues.

Hume balances one dogmatism against another, and he defuses their violent potentials not only through charitable and sympathetic reportage but also through waves of skeptical argument. As Richard Dees observes, Hume's skepticism in the Dialogues about metaphysical questions and the capacities of the human mind to settle them is resolved not in favor of a demonstrable, universally accepted conclusion but rather sociability, "friendship," and neutralized potential violence. ${ }^{40}$ It is a practice of writing that is therapeutic both as an example and in its logic. Hume's Philo observes:

That the dispute concerning Theism ... is merely verbal, or perhaps, if possible, still more incurably ambiguous, will appear upon the slightest enquiry. ... The Theist allows, that the original intelligence is very different from human reason: The Atheist allows, that the original principle of order bears some remote analogy to it. Will you quarrel, Gentlemen, about the degrees, and enter into a controversy, which admits not of any precise meaning, nor consequently of any determination? (D 12.7) $)^{41}$

Sam Hall puts it well when he writes about Part 12 of the Dialogues: "Hume's political message is the exemplary performance, and endorsement as ideal, of the life that his characters share, despite their disagreements." ${ }^{42}$

In matters of state, Hume is like other early modern liberal theorists insofar as his objective is peace or political ataraxia. Though Hume says Hobbes's political is "fitted only to promote tyranny" (H 6.42.153), when Hobbes describes the pre-social bellum omnium contra omnes or war of all against all, his objective is clearly on the contrary to overcome it. ${ }^{43}$ So it is, too, for Locke

${ }^{38}$ Immerwahr (1992), 304.

${ }^{39}$ Immerwahr (1994).

40 Dees (2002).

${ }^{41}$ Wright draws a connection between Hume's remark about the question of the deity's existence being a merely "verbal" dispute and a similarly skeptical remark by Ralph Cudworth concerning arguments about the ta adela of natural powers: the "Controversie whether the Energy of the Plastick Nature, be Cogitation, or no, seems to be but a Logomachy, or Contention about Words"; Wright (1983), 171. As this passage was a late addition to the 1779 edition of Hume's Dialogues, one may think of it as "Hume's final attempt to clarify the character and import of his scepticism"; Harris (2015), 570n212.

${ }^{42}$ Clark (2013), 72.

43 In De Cive (1651), Chapter 1, Paragraph 12, Hobbes writes: "it cannot be deny'd but that the naturall state of men, before they entr'd into Society, was a meer War, and that not simply, but a War of all men, against all men." Hume does not seem to think it possible for human beings to exist in a non-social condition, but he also thinks that without rules of justice humans will sink into a condition 
and Rousseau; both labor in towards the goal of ending or at least mitigating conflict and social discord. Adam Ferguson and Karl Marx, in contrast, argue that conflict is a good, though Marx remains committed to the liberal idea of finally overcoming it, too. It would take an anti-liberal like Carl Schmitt to argue for war as a social good. ${ }^{44}$

As a skeptic, however, Hume is unlike other liberal theorists because he is not concerned with the establishment of a political ideal or defending the conclusions of a dogmatic political science. For that reason interpreters have often been confounded by the facility with which he seems to endorse and criticize both Tory and Whiggish ideas. History, in fact, yields the skeptical lesson that the political ideals for which philosophers contend produce discord without end. Tranquility and liberty are the fruits of true skeptical political philosophy, and they prove in experience more important than realizing theoretical ideals:

the study of history confirms the reasonings of true philosophy; which, shewing us the original qualities of human nature, teaches us to regard the controversies in politics as incapable of any decision in most cases, and as entirely subordinate to the interests of peace and liberty. (T 3.2.10.15, SBN 562)

For Hume, the principal political adversary is conflict itself, especially, during the historical moment in which he lived, "faction." In his essay, "That Politics May Be Reduced to a Science," for example, Hume writes that: "There are enow of zealots on both sides who kindle up the passions of their partizans, and under pretence of public good, pursue the interests and ends of their particular faction. For my part, I shall always be more fond of promoting moderation than zeal," though he allows there-skeptical as he is even of a purely anti-zealous position-that measured zeal for the public good may be desirable (ES 27). In "Of Parties in General," Hume elaborates further on the danger faction poses: "Factions subvert government, render laws impotent, and beget the fiercest animosities among men of the same nation, who ought to give mutual assistance and protection to each other" (ES 55). They also aid the enemy and distort clear thinking. Although usurper Henry I was flawed in many ways, according to Hume the "chief merit of this monarch's government consists in the profound tranquility, which he established and maintained throughout all his dominions during the greater part of his reign" (H 1.6.273).

similar to the one Hobbes describes. He even uses Hobbes's phrase in saying so: "Human nature cannot, by any means, subsist, without the association of individuals; and that association never could have place, were no regard paid to the laws of equity and justice. Disorder, confusion, the war of all against all, are the necessary consequences of such a licentious conduct"; Hume (1998), 4.3, SBN 206, emph. mine; hereafter "EM."

${ }^{44}$ Schmitt (1927).

Araucaria. Revista Iberoamericana de Filosofía, Política, Humanidades y Relaciones Internacionales, año 20, $\mathrm{n}^{\circ} 40$. Segundo semestre de 2018. Pp. 371-401. ISSN 1575-6823 e-ISSN 2340-2199 doi: 10.12795/araucaria.2018.i40.17 
Nevertheless, Hume does, in "Idea of a Perfect Commonwealth," develop his own "imaginary republic" (ES 514), one in part inspired by James Harrington's 1656 Oceana. Hume's model, however, unlike Harrington's, is best read as a contingent skeptical instrument of faction management rather than as a representation of a purportedly eternal truth revealed by empirical or $a$ priori political science; and it is in this skeptical sense, more precisely than Sabl recognizes, that Hume may be said to take a "technological attitude towards politics." ${ }^{45}$ (The observance of technai is, of course, one of the components of the Pyrrhonian Fourfold.) Moreover, it is by the use of skepticism in politics in this more extensive way than Forbes realizes that Hume wishes to educate the Hanoverian court. ${ }^{46}$ Hume's overriding concern is evident when he remarks at the close of the essay:

I would only persuade men not to contend, as if they were fighting pro arts \& focis [for altars and hearths], and change a good constitution into a bad one, by the violence of their factions. (ES 31)

Various political arrangements can be good or bad, including his, but that is no reason not to offer a plan for contemporary society (and ideal commonwealth) that solves the problems that confront it. The key is to consider the ideal in a skeptical spirit. No such plan is for the Humean true skeptic an eternal truth.

A Byzantine machine, Hume's republic carefully arranges its parts to establish a complex and redundant system of checks and balances designed to cancel out faction through political isosthenia in order to cultivate social ataraxia and moderated political passions. For that reason, Hume's essay is often compared with James Madison's Federalist Papers \#10, which is focused upon the same anti-factional end. ${ }^{47}$ Hume's advances a republican model and that not because it satisfies some a priori ideal of the political good but rather because: "Though it is more difficult to form a republican government in an extensive country than in a city; there is more facility, when once it is formed, of preserving it steady and uniform, without tumult and faction" (ES, 527). That is in part so because the "differences of moral sentiment, which naturally arise from a republican or monarchical government, are also very obvious; as well as those which proceed from general riches or poverty, union or faction, ignorance or learning" (EM Dialogue 51, SBN 340-41).

${ }^{45} \mathrm{Sabl}(2015), 163$.

${ }^{46}$ Forbes (1975), Chapter 3, "Political Obligations for 'Moderate Men'," $91 \mathrm{ff}$.

47 Adair (1956/57). Adair writes about Federalist 10 that Madison was "not only using the behavioral science techniques of the eighteenth century, but turning to the writings of David Hume himself for some of the suggestions concerning an extended republic"; as reprinted in Livingston \& King (1976), 408.

Araucaria. Revista Iberoamericana de Filosofia, Política, Humanidades y Relaciones Internacionales, año 20, ${ }^{\circ} 40$. Segundo semestre de 2018. Pp. 371-401. ISSN 1575-6823 e-ISSN 2340-2199 doi: 10.12795/araucaria.2018.i40.17 
The balancing method of Hume's skeptical writing about politics also shows itself in his dyad of essays, "Of the Original Contract" and "Of Passive Obedience," written shortly after the Jacobite uprising of $1745 .{ }^{48}$ In the first, Hume undermines the social contract theory of obligation characteristic of Whigs and liberals, in the second the passive obedience theory of the Tories. On the one hand, social contract theory is a fiction that itself presumes prior agreement. On the other hand, while in general Hume conservatively aligns himself with standing authority, he understands from a "pragmatic and sceptical" perspective that passive obedience sometimes runs up against nature and human beings' opinions concerning their own interest: "'Tis certain, therefore, that in all our notions of morals we never entertain such an absurdity as that of passive obedience, but make allowances for resistance in the more flagrant instances of tyranny and oppression" (T 3.2.9.4, SBN 552). ${ }^{49}$ Indeed, there seems in general in the essays, and in particular in "Of Liberty and Despotism," to be "a striking scepticism as to the ultimate importance of the distinction between 'free' governments and absolute ones." 50

On the one side of the balance, Hume sets himself for the sake of ataraxia in a stance inclining towards allegiance to standing authority: "I must confess, that I shall always incline to their side, who draw the bond of allegiance very close, and consider an infringement of it, as the last refuge in desperate cases, when the public is in the highest danger, from violence and tyranny" (ES 489; "Of Passive Obedience"). ${ }^{51}$ In the History, just after discussing the regicide of Charles I without praise for those who toppled him and with apparent sympathy for the monarch, Hume recommends "hiding the truth from the populace" of "the doctrine of resistance" (H 5.544).

On the other side, Hume there in the History affirms that the doctrine of resistance is "the truth," and in doing so he does just the opposite of concealing it. ${ }^{52}$ Hume accepts rebellion and revolution in highly constrained

${ }^{48}$ Although this dyad was incorporated as seemingly a dialectical pair into the 1748 "Third Edition, Corrected" of Essays, Moral and Political, the two were also published with a third essay, "Of National Characters," in a stand alone volume in Edinburgh and London that same year as Three Essays, Moral and Political (Andrew Millar \& Alexander Kincaid).

${ }^{49}$ Harris (2015), 236.

${ }^{50}$ Harris (2015), 184. The essay, "Of Civil Liberty," was originally titled "Of Liberty and Despotism," and the various editions of his essays between 1741 and 1754 bear the original title. There Hume also in the revised essay commonly substituted "absolutism" for "despotism."

${ }^{51}$ Laursen (2010) identifies a string of moderate or, in his terms, "tame" skeptics who emerged in Germany in the late eighteenth century. These thinkers advocated skepticism about epistemological matters, moderation of the passions, but took no issue with the status quo of society: Louis de Beausobre, author of Le Pyrrhonisme du Sage (1754), renamed Le Pyrrhonisme raisonnable (1755); Jean Bernard Mérian, author of "Sur le phénoménisme de David Hume"; and Louis Frédéric Ancillon, author of "Dialogue entre Berkeley et Hume" (1799), "Doutes sur les bases du calcul des probabilités." Laursen argues that these authors demonstrate that skepticism may be neither conservative nor subversive but merely passive in the face of the status quo. On Mérian's essay on Hume, see Laursen and Popkin (1997).

${ }_{52}$ Merrill dissects this curious, ironic, and paradoxical moment in Merrill (2005).

Araucaria. Revista Iberoamericana de Filosofía, Política, Humanidades y Relaciones Internacionales, año 20, $\mathrm{n}^{\circ} 40$ Segundo semestre de 2018. Pp. 371-401. ISSN 1575-6823 e-ISSN 2340-2199 doi: 10.12795/araucaria.2018.i40.17 
circumstances: "our submission to government admits of exceptions, and that an egregious tyranny in the rulers is sufficient to free the subjects from all ties of allegiance" (T 3.2.9.1, SBN 549). Hume offers implicit support to the Glorious Revolution when he calls the settled regime that followed "if not the best system of government, at least the most entire system of liberty that ever was known amongst mankind" (H 6.71.531; cf. 2.23.525). Hume cites Spain's Philip II and the Roman emperors, Nero and Dionysius (T 3.2.9.4, SBN 552; ES 426), as well as Tiberius, Caligula, Domitian (ES 94), Nabis, and Agathocles (ES 409-10) as rulers so exceptionally tyrannical as to warrant their overthrow.

Accordingly we may observe, that this is both the general practice and principle of mankind, and that no nation, that cou'd find any remedy, ever yet suffer'd the cruel ravages of a tyrant, or were blam'd for their resistance. Those who took up arms against Dionysius or Nero, or Philip the second, have the favour of every reader in the perusal of their history; and nothing but the most violent perversion of common sense can ever lead us to condemn them. (T 3.2.9.4, SBN 552)

There are for Hume limits to obedience. Sounding almost like a liberal ideologue, Hume writes in Book 3 of the Treatise: "in the case of enormous tyranny and oppression, 'tis lawful to take arms even against supreme power; and that as government is a mere human invention for mutual advantage and security, it no longer imposes any obligation, either natural or moral, when once it ceases to have that tendency" (T 3.2.10.16, SBN 563). And furthermore: "Those, therefore, who wou'd seem to respect our free government, and yet deny the right of resistance, have renounc'd all pretensions to common sense, and do not merit a serious answer" (T 3.2.10.16, SBN 564).

Perhaps it is proper, as James Harris puts it, to think of Hume the political skeptic as "defining and developing a philosophy of politics that was as sceptical about the myths of Whiggism as it was about the myths of Toryism." ${ }^{53}$ On the other hand, Thomas Merrill sees a deeper point of political philosophy made in Hume's "playful" and seemingly contrary rhetoric concerning these questions: "Hume's playful rhetoric thus leads into his view of the deeper paradoxes within every political society" concerning authority and liberty, as well as ideal perfections and practical limitations - contradictions or tensions, one might say, that skepticism is well placed to handle. ${ }^{54}$

\footnotetext{
${ }^{53}$ Harris (2015), 131.

${ }_{54}$ Merrill (2005), 259. The rhetoric also, in Merrill's formulation, achieves the delicate political objective of keeping "the right of rebellion in the public mind without encouraging its exercise" (282). This would have been especially important to Hume since in his own historical moment, the right of rebellion was most likely to be exercised by Jacobites, whom Hume opposed.
} 
Hume's criticisms are not advanced in the service of a new and different political dogma but rather for the sake of skeptical ataraxia and metriopatheia. ${ }^{55}$ In the very next essay after these two balancing poles, Hume describes in "Of the Coalition of Parties" his method in terms of balancing and moderate emotion directly in conjunction with skepticism about reason:

There is not a more effectual method of promoting so good an end than to prevent all unreasonable insult and trump of one party over the other, to encourage moderate opinions, to find the proper medium in all disputes, to persuade each that its antagonist may possibly be sometimes in the right, and to keep a balance in the praise and blame, which we bestow on either side. The two former Essays, concerning the original contract and passive obedience, are calculated for this purpose with regard to the philosophical and practical controversies between the parties, and tend to show that neither side are in these respects so fully supported by reason as they endeavour to flatter themselves. We shall proceed to exercise the same moderation with regard to the historical disputes between the parties, by proving that each of them was justified by plausible topics; that there were on both sides wise men, who meant well to their country; and that the past animosity between the factions had no better foundation than narrow prejudice or interested passion. ${ }^{56}(\mathrm{ES}, 494)$

\section{At the closing of the History of England he writes:}

And forgetting that a regard to liberty, though a laudable passion, ought commonly to be subordinate to a reverence for established government, the prevailing faction has celebrated only the partisans of the former, who pursued as their object the perfection of civil society, and has extolled them at the expense of their antagonists, who maintained those maxims, that are essential to its very existence. But extremes of all kinds are to be avoided; and though no one will ever please either faction by moderate opinions, it is there we are most likely to meet with truth and certainty. (H 6.71.533-34)

If not truth, then at least moderation offers what is useful, stable, durable, and satisfactory to the best demands of human scrutiny.

Without connecting Hume's strategy to skeptical practice, Duncan Forbes offers this otherwise insightful summary of it: "Whig theory and the conscientious scruples of Jacobites are both condemned by a political

${ }^{55}$ Merrill reads Hume's skeptical questioning as a means of forging a political science that makes a space for the radical questioning of skepticism; e.g. Merrill (2015b), 26: "Hume's intention is not simply to promote moderation, as important as that is. He also makes an argument about why radical questioning is necessary for politics and even attractive for its own sake." Merrill is right that Hume's radical questioning serves political ends (though, as we have seen, sometimes not questioning does, too). I wish to stress a deep continuity between Hume's politics and his skepticism in what might be called skeptical political ends, ends that include moderation and ataraxia, as well as zetetic and critical questioning in the activity of methodizing and correcting. Skepticism informs Hume's politics.

${ }^{56}$ Quoted by Sabl (2015), 153. 
philosophy fashioned to meet the needs of forward-looking 'moderate men' in a modern progressive society." ${ }^{57}$ As it is when dealing with dogmatism generally, says Sextus Empiricus (PH 1.12.25), in the tumult of political life "extremes of all kinds are to be avoided" in favor of "moderate opinion." That may be the best that finite human beings can achieve..$^{58}$

\section{Customs, Toryism, and Conservatism}

Not everyone, however, has understood Hume to be a progressive thinker. Of course, neither "conservative" nor "progressive" were terms that Hume would have used to characterize his political views. Nevertheless, that Hume holds our lives to be grounded in habit, custom, and history has led a number of commentators to misunderstand him as a deeply conservative traditionalist of the same stream that produced Edmund Burke (1729-97) and arguably Michael Oakeshott (1901-1990). ${ }^{59}$ In Laurence Bongie's phrase, for example, Hume is the "prophet of the counter-revolution," since he precedes Burke. ${ }^{60}$ Livingston, who wrote the foreword to the Liberty Fund's reissue of Bongie's volume, pursues a similar reading, calling Hume even "the first conservative philosopher." 61 It is an interpretation in my view, however, that misunderstands the normative and critical power of Hume's thought, and it rests on a fallacy of false alternatives.

John Stuart Mill concluded that Hume's "absolute skepticism in speculation very naturally brought him round to Toryism in practice...." ${ }^{62} \mathrm{Sir}$ Leslie Stephen, who had done so much to define Hume to a British readership, accused Hume not only of a "heretical scepticism" that vitiated philosophy and history but also of a "cynical conservatism" that "inclines to the side of authority as the most favorable to that stagnation which is the natural ideal of a sceptic." 63 Biographer James Harris acknowledges that "from early on Hume had been sceptical of the standard Whig view of the Stuarts as tyrannical usurpers." Thomas Jefferson is well known for having read Hume as an illiberal Tory, and

\footnotetext{
57 Forbes (1975), 96.

${ }^{58}$ Quoted by Wiley (2012), 154, cf. 292n121.

${ }^{59}$ Burke (1790) and Oakeshott (2010) as well as Oakeshott (1947). See also Wolin (1954/1976).

${ }^{60}$ Bongie (2002). See Resnick (1996). Cf. Mossner (1941).

${ }^{61}$ Livingston (1984), 310.

62 Mill (1838), 10:80.

63 Stephen (1949), 181. See Wolin (1954/1976), 999, and Harris (2015), 7.

${ }^{64}$ Harris (2015), 329. Harris also writes that Hume become increasingly doubtful about the Whigdominated political settlement to the Glorious Revolution. In the wake of the public disturbances following the 1768 elections, Hume became "even more sceptical about the balance struck between liberty and authority by the post-1688 constitution..." (409). Harris reads Hume's despair over the British government's ability to cope with its debts as "further reason" for Hume "to be sceptical of jingoistic celebrations of the virtues of British liberty" (425).
}

Araucaria. Revista Iberoamericana de Filosofia, Política, Humanidades y Relaciones Internacionales, año 20, $\mathrm{n}^{\circ} 40$ Segundo semestre de 2018. Pp. 371-401. ISSN 1575-6823 e-ISSN 2340-2199 doi: 10.12795/araucaria.2018.i40.17 
in an 11 June 1807 letter to John Norvell Washington, Jefferson opined, for example, that:

\begin{abstract}
as we have employed some of the best materials of the British constitution in the construction of our own government, a knowledge of British history becomes useful to the American politician. There is, however, no general history of that country which can be recommended. The elegant one of Hume seems intended to disguise \& discredit the good principles of the government, and is so plausible \& pleasing in its style \& manner, as to instil its errors \& heresies insensibly into the minds of unwary readers. ${ }^{65}$
\end{abstract}

To William Duane on 12 August 1810, Jefferson complained at a higher pitch that Hume's History "has spread universal toryism over the land." ${ }^{66}$ As Jefferson aged, his condemnations became more impassioned. On 25 November 1816, Jefferson wrote to John Adams a remark that seems almost apoplectic: "This single book has done more to sap the free principles of the English Constitution than the largest standing army of which their patriots have been so jealous." ${ }^{\prime 67}$ Jefferson and others who read Hume as a reactionary are mistaken.

In the Treatise and, as we have seen, in "Of the Original Contract" Hume does attack social contract theory, the darling of political liberals and Whigs, in its attempt to establish rationally the basis of state and social authority ( $\mathrm{T}$ 3.2.1-11, SBN 477-569) ${ }^{68}$ It is, indeed, in the context of refusing a contractual justification for the Glorious Revolution - the Whiggish justification - that in a letter to Kames he calls himself a "sceptical” Whig (LT 1:111,\#62). Hume found Wilkes and the radical Whigs to be dangerous. Hume, yes, seems decidedly conservative, too, when he argues that "long possession" (T 3.2.10, SBN 556), simple "present possession" (T 3.2.10, SBN 557) and even "conquest" can establish sovereign authority over territory, especially once habits of obedience are in place. Not only limited government by consent but even "absolute government" (T 3.2.9, SBN 549) is legitimate, for Hume, a suggestion that is anathema to liberals. In a passage added to the essay "That Politics May Be Reduced to a Science" in the third (1748) edition of the Essays, Hume confirms the skeptical and anti-republican view that "ages of greatest public virtue are not always most eminent for private virtue" (ES 25). ${ }^{69}$

Hume refuses the doctrine of Lockean or Jeffersonian natural rights, associated with liberals and so centrally important to them in leveraging political demands of the sort, for example, Thomas Paine advanced in The Rights of

${ }^{65}$ Jefferson (1807), 91

${ }^{66}$ Jefferson (1810), 293.

${ }^{67}$ Jefferson (1816), 498-99.

${ }^{68}$ See also Hume's essay, "Of the Origin of Government" (ES, 37-41).

${ }^{69}$ Harris (2015), 246. This is the wording of the 1748 edition. The 1777 edition has "ages of public spirit."

Araucaria. Revista Iberoamericana de Filosofía, Política, Humanidades y Relaciones Internacionales, año 20, $\mathrm{n}^{\circ} 40$ Segundo semestre de 2018. Pp. 371-401. ISSN 1575-6823 e-ISSN 2340-2199 doi: 10.12795/araucaria.2018.i40.17 
Man (1791). Indeed, although Thomas Jefferson misunderstood Hume as a Tory, he properly understood that Hume's History of England (vol. 5) does not portray Charles I as a simple tyrant or follow a Whiggish historiography that posits an ancient constitution and charts the unfolding of liberty onward from Magna Carta, or, as became popular, from prior to it in Anglo-Saxon social practices, through to its full flowering in the English Civil War and the Glorious Revolution. ${ }^{70}$ In fact, Hume seems sympathetic with, if not to endorse fully, a cyclical rather than a progressive view of history, marking the cycling rise and fall of the arts and sciences (ES 135ff.) and the flux and reflux of religious ideas (N 8.1). ${ }^{71}$

I say not fully endorse because at moments Hume seems to regard religious ideas as in fact contrary to nature and on the whole therefore something other than just the products of natural cycling-e.g. Section 12 of the Natural History of Religion, "With regard to Doubt or Conviction" (N 12.15). The traditionalist reading on the whole, in fact, collapses in the face of what Robert Denoon Cumming observes in opposition to Mill: the "passage from skepticism to traditionalism ... involves an over-simplification of the relationship between theory and practice as treated by Hume." 72 How so?

\section{Progressive and Critical Customs}

The traditionalist conservative reading of Humean philosophy runs aground on the insistence with which Hume's work advances reformist and even progressive ideas, too. Hayek may overstate the case. He is right to observe that since Hume was not entirely sanguine about human faculties, he was also not terribly optimistic about government's prospects to advance positive goods. ${ }^{73}$ Nevertheless, Hume's own political positions are frequently inclined in liberal and Whiggish directions, and the implications that may be drawn from his theory are in many ways radical. Hume not only deploys skeptical balancing but also generates, as we have seen, a decidedly progressive republican architecture to ameliorate the effects of faction upon the state in "On the Idea of a Perfect Commonwealth.” Hume was a supporter if not a dogmatic defender of

\footnotetext{
${ }^{70}$ Laursen (2015) 196ff. observes how Christian Thomasius, author of Philosophia aulica, crafted a position not unlike this conservative interpretation of Hume. Thomasius used skepticism to undermine the theological influence of the clergy and to subvert the prosecution of heretics, but he also gave a kind of deference to royal power, albeit on secular grounds.

${ }^{71}$ See Susato (2015), 216ff. for a more extensive account of Hume's cyclical view of history and civilization.

${ }_{72}$ Cumming (1969), 2:236; quoted by Wiley (2012), 14.

${ }^{73}$ Hayek (1966), 359: "The great sceptic, with his profound conviction of the imperfection of all human reason and knowledge, did not expect much positive good from political organization. $\mathrm{He}$ knew that the greatest political goods, peace, liberty, and justice, were in their essence negative, a protection against injury rather than positive gifts."
}

Araucaria. Revista Iberoamericana de Filosofia, Política, Humanidades y Relaciones Internacionales, año 20, $\mathrm{n}^{\circ} 40$ Segundo semestre de 2018. Pp. 371-401. ISSN 1575-6823 e-ISSN 2340-2199 doi: 10.12795/araucaria.2018.i40.17 
the aspirations of the Glorious Revolution and of American independence, both liberal and Whiggish projects. As early as 1766, Hume expressed sympathy with the colonists in their opposition to the crown's authority in the Stamp Act of the previous year (LT 2.21, \#307; LT 2.43,\#321), and by 1768 he advocated complete independence. Declining a request from Baron William Mure in 1775 to urge from the crown strong action against the colonies, Hume replied: "I am an American in my Principles, and wish we would let them alone to govern or misgovern themselves as they think proper" (LT 2.303, \#510). ${ }^{74}$

Although he was a racist, as the infamous footnote he appended to the 1753 essay "Of National Characters" indicates (ES 208n10), Hume nevertheless also condemned slavery. In "Of the Populousness of Ancient Nations," he observes that slavery is "more cruel and oppressive than any civil subjection whatsoever" (ES 383; see 383-98); his personal response to the practice was "disgust" (ES 384). Like liberal political writers, Hume praised emerging liberties of thought and publication in, for example, "Of the Liberty of the Press," "Of Civil Liberty," and "Of the Independence of Parliament." More generally, Hume, though he was aware of its potential for vice, also supported the development of new economic relations and the newly developing natural and social sciences (e.g., "Of Commerce").

Hume was a friend of the revolutionary, Benjamin Franklin, and given all this it should be unsurprising that Hume's essays were frequently consulted for supportive resources by liberal revolutionaries and progressives in the newly established United States. ${ }^{75}$ George Washington, Samuel Adams, John Dickinson, Charles Lee, John Randolph of Roanoke, Benjamin Rush, and Robert Carter of Nomini Hall, as well as Franklin, are all thought to have been positively influenced by Hume. The 1780 Committee on Finance in the Continental Congress, for example, studied Hume's economic essays, and in the 1787 Philadelphia Congress, Hamilton appealed to Hume in arguing against legally penalizing corrupt office holders. Hume also apparently taught Hamilton that an expanding commercial order is consistent, even complementary, with a stable republic.

\subsection{Cosmopolitan and Organic Customs}

Hume is no organic nationalist either. He articulates cutting-edge naturalistic accounts of mind, political theory, and epistemology that are, contra Dees and Livingston, more than local in the way conservative nationalists argue. Hume works, as Richard Dees has argued, to understand historical figures in their

\footnotetext{
${ }^{74}$ Hayek (1966), 340, reads Hume as a liberal: "it is in Hume and not, as is commonly believed, in Locke ... that we find the fullest statement of these doctrines"-i.e. a Whiggish and liberal doctrines.

75 See Livingston (1990), Spencer (2010), Stourzh (1970), Wills (1981), Werner (1972).
} 
own context, in terms of the values, ideas, and rationality available to them at their time and not by timeless and placeless standards of judgment. ${ }^{76}$ But Hume also aspires to a kind of political science or almost-science ("That Politics May Be Reduced to a Science," 1742), and he engages in a kind of discourse about political virtue that speaks from a skeptical location but nevertheless in a universal voice - just as he does in natural science, morals, and aesthetics. ${ }^{77}$ One might think of Hume's political voice even, in this sense, as a cosmopolitan voice, the voice of a cosmopolitan skeptic.

There is a political implication to this. For Hume, the locus of proper or true political reflection is not the national state as it came to be understood in nineteenth and twentieth-century political thought. Livingston is right that Hume would reject as a superstitious fiction the state as an organic whole as it is given modern voice through Rousseau's idea of a "general will" that transcends all particular wills and displaces a divine general providence in guiding the good of society. ${ }^{78}$ There are, however, a number of worrisome passages that suggest something like Giovanni Gentile and Mussolini's well known 1932 work, La dottrina del fascismo, and the organicist view of the political order it draws from Hegel. It is a political doctrine that radically localizes political truth inside the supposedly authentic ethnos, nation "state," or Volk. In the essay, "Of the Rise and Progress of the Arts and Sciences," Hume writes about a "spirit and genius" that is "diffused throughout the people among whom they arise" (ES 114; cf. H1.9.375). Similarly, in "Of Refinement in the Arts," Hume asserts that the "spirit of the age affects all the arts" and pervasively "the minds of men" of that age (ES 271). But an understanding of skepticism deflates the apparent metaphysical collectivism of these passages - not only because of skeptical constraints about positing metaphysical Geistes but also with regard to speaking in a universal and dogmatic voice.

For the same reasons, a proper Humean skepticism would reject socialist ideas of class and the "people" as metaphysical entities (e.g. as manifest in Jules Vallès's newspaper, Le Cri du Peuple from the Paris Commune, 1871). For Hume, instead, while our apparently common and natural human fatalities inform our speaking and thinking about more than our own parochial location, the truths of skepticism still recollect our finitude and the lack of a comprehensive or absolute science we seem fated to suffer. While Hume is methodologically committed to a kind of contextualism, and while Hume writes about a collective "spirit" and about a "general interest" (ES 525) in a universal

\footnotetext{
${ }^{76}$ Dees (2008).

${ }^{77}$ Famously, Hume writes in "That Politics May Be Reduced to a Science" that: "So great is the force of laws and of particular forms of government, and so little dependence have they on the humors and tempers of men, that consequences almost as general and certain may sometimes be deduced from them as any which the mathematical sciences afford us" (ES, 16). For an interpretation of Hume as a social scientist despite his skepticism, see Hardin (2007).

${ }^{78}$ Livingston (1998), $367 \mathrm{ff}$.
}

Araucaria. Revista Iberoamericana de Filosofia, Política, Humanidades y Relaciones Internacionales, año 20, $\mathrm{n}^{\circ} 40$ Segundo semestre de 2018. Pp. 371-401. ISSN 1575-6823 e-ISSN 2340-2199 doi: 10.12795/araucaria.2018.i40.17 
voice, skeptics understand that the voice is just his own as it calls out to others in the hope of agreement, perhaps even making a claim upon agreement, but a claim without ultimate or transcendent authority. It does not pretend to give voice to the divine or to a universal or collective being, and it suspends judgment on dogmatic methodological holism as well as methodological individualism. Hume's, that is to say, is a universal and even cosmopolitan but still skeptical political science of nothing more than doxa, ataraxia, isosthenia, and epoche.$^{79}$

\subsection{Reflective, Critical, and Methodized Customs}

Hume, along these lines, writes famously in the first Enquiry (1748) that, properly undertaken, "philosophical decisions are nothing but the reflections of common life, methodized and corrected" (E 12.3, SBN 121). The proper contrasting alternatives for Humean political theorists and scientists, accordingly, are not those of transcendence vs. custom but rather methodized custom vs. unreflective custom. It is, however, in misunderstanding this methodizing and correcting project that those who have interpreted Hume as a traditionalist have erred. To infer from Hume's rejection of false philosophical transcendence a normative embrace of traditionalist or organicist conservatism depends upon the erroneous position that traditionalist or organicist conservatisms are the only alternatives to false philosophy. They are not. Hume the skeptical, philosophical critic articulates another alternative.

When Humean "reflection" casts its gaze upon custom, it can, when properly disciplined, generate what Hume calls "general rules" of a "second influence" ( $\mathrm{T}$ 1.3.13.12, SBN 150) rooted, as we are now in a position to appreciate, in custom itself. The power of general rules was not lost on Gilles Deleuze, who read them as central to Hume's philosophy and pervasive across it. ${ }^{80}$ These rules can subsequently turn back upon custom to methodize and correct it, but not forever or with the presumption of final closure. Reflectively generated and critically applied general rules of this sort include political rules.

Although in common life we act by habit and custom in generally unreflective ways, as if by a "secret operation" (T 1.3.12.5, SBN 104), through our capacity for reflection we can nevertheless, like the Owl of Minerva, later look back upon and regulate the "unphilosophical probabilities" or beliefs of habit and custom by deploying reflectively generated and critical general rules (T 1.3.13.7ff., SBN 146ff.). Custom, in short, can itself for Hume become the ground - a ground consistent with Pyrrhonism-for revising and reforming custom, even in what to the observant skeptical thinker may seem to be a

79 Schmidt (2003), 383-84, roots Hume's resistance to a collectivist and organicist metaphysics in his empiricism rather than, as I do, his skepticism; cf. Livingston (1984), 225-26.

${ }^{80}$ See Deleuze (1953), Chapter Two, "Cultural World and General Rules." 
progressive way. For example, Hume criticizes in the essay, "Of Commerce," the conservative idea that France's ancient customs of agriculture should be normative in relation to the nation's future. ${ }^{81}$ As John Christian Laursen aptly puts it, "The key to Hume's analysis of socially destructive habits is that one kind of custom can be used to correct others. ... Our rules concerning the stability of possession, the transfer of possession by consent, and the performance of promises are a product of such reflection. The habit of philosophy thus provides tools for the criticism of other habits." 82 That includes critical and progressive habits of a skeptical sort-habits without the requirement of an absolute, independent, or eternal standard of progress or judgment. About true skeptical philosophy, Hume writes: "It enters more into common life; moulds the heart and affections; and, by touching those principles which actuate men, reforms their conduct, and brings them nearer to that model of perfection which it describes" (E 1.3, SBN 6-7). ${ }^{83}$

While criteria of criticism and judgment are initially generated through a reflective engagement with experience, by custom criteria of this sort become durable. They thereby compose what might be regarded, in contrast to mere "prejudice," second order customs of criticism that solidify as if a kind of cultural sentiment. ${ }^{84}$ Just so Hume writes about "the gradual change of our sentiments and inclinations, and the different maxims, which prevail in the different ages of human creatures" (E 8.11, SBN 86). Hume describes a correlative process of locating skeptically universal normative standards in his influential essay on aesthetics, "On the Standard of Taste"; but of course the process of generating second-order critical customs is not restricted to aesthetic judgment. Criticism is underwritten by a similar process in scientific, moral, and also political judgment. In this way, standards of scientific proof, experiment, and evidence change. Habits and customs for Humean skeptics may be revised, not by metaphysical appeals to the divine or through self-evident principles of reasoning, but rather by appeal to second-order principles self-consciously generated from within common life itself. Protectionism to preserve a traditional economy might be criticized, and Hume does so. ${ }^{85}$ Conversations, dialogues, and contests about these and other politically charged topics situated

\footnotetext{
${ }^{81}$ Harris (2015), 270-71.

${ }^{82}$ Laursen (1992), 166. On Hume's ideas about generating and sustaining social-political stability, see Whelan (1985); cf. Immerwahr (1992).

${ }^{83}$ See Stewart (1992), Chapters 5-6, for a optimistic account of the potential for change in Hume's corrective politics. Cited by Merrill (2005), 279n26. As Merrill says, too, for a less optimistic account, see Miller (1981).

84 "It might be imagined," writes Wittgenstein along similar lines, "that some propositions, of the form of empirical propositions, were hardened and functioned as channels for such empirical propositions as were not hardened but fluid; and that this relation alerted with time, in that fluid propositions hardened and hard ones became fluid. The mythology may change back into a state of flux, the river-bed of thoughts may shift." (On Certainty, §§95-97)

${ }^{85}$ Harris (2015), 276.
} 
in common life might similarly in a Humean way enlist principles concerned with the usefulness, durability, and pleasure. Humean skeptics might revise, for example, the contingent habits we call "marriage," "gender," "family," "love," "parent," "liberty," and "fairness," that people currently inhabit, as well as alternatives to them. Through critical Humean second-order reflections grounded in common life, people might inhabit differently or cease to inhabit the habits of race. Within a network of general rules of a second influence, one might even speak of progress different from the metaphysical and dogmatic progress of liberals. Call it a kind of provisional, unsponsored and skeptical progress.

Reflectively generated second-order general rules subvert the metaphysical and epistemological realisms and enthusiasms dogmatists had recognized as philosophy. But this same kind of second-order reflection subsequently "saves" philosophy by offering a new, unsponsored set of habits that, through philosophical theory and criticism, changes the direction of human life. It saves the political order, too. This new, reflective direction resolves the puzzle facing traditionalist readers of explaining how Hume's rooting so much of our lives in habit, custom, and history can be made consistent with normative, reformist, and progressive criticism. As he says at T 1.3.13.12, it may seem to a dogmatist a "contradiction" that the habits constitutive of critical general rules subvert (through skepticism) rationalism but also underwrite critical judgment. ${ }^{86}$ But Hume's theory of habit exhibits how customs may be used critically and progressively to correct and to modify one another without the requirement of ultimate grounds beyond the practices of human life itself, or what Hume calls "common life." In short, the reflective and progressive use of habit and custom as it functions in second-order general rules saves Hume from being understood as a Burkean conservative traditionalist. ${ }^{87}$ It offers instead a "progress of the sentiments" (T 3.2.2.25, SBN 499) and a set of practices in Humean thinking that is both critical and skeptically progressive, even new practices that offer resistance to the existing political order.

\subsection{Zetetic Politics}

In addition to the way Hume adopts skeptical norms of doxa and phainomena, ataraxia, isosthenia, and epochê, Humean politics may also be described as

${ }^{86}$ It is to just this replacement of reason with habit and association that leads Henry Allison to judge in favor of Kant over Hume; see Allison (2008).

${ }^{87}$ I write of the traditionalist conservatism that finds inspiration in Burke but not Burke himself. Burke did criticize the French revolution by appeal to the importance of customs and tradition, but on that same basis he also supported the American colonies against the crown, Irish Catholic rights, and various kinds of domestic reform in Britain and India. This strategy of appealing to custom to criticize other customs for the sake of dynamic and innovative reform in politics not only connects Burke to Hume but also to more progressive political traditions. 
characterized by Pyrrhonian zetesis: "The Sceptic School, then, is also called 'Zetetic' from its activity in investigation and inquiry..." (PH 1.3.7). The zetetic quality of Hume's political thought also militates against a conservative reading of it. Louis Loeb has recognized that the mere opposition of arguments and other appearances does not automatically result in isosthenia and ataraxia for Hume. ${ }^{88}$ Those oppositions can produce a churning "combat" (T 1.4.2.37, SBN 205) among competing principles and beliefs, as well as "dangerous" perhaps even "fatal" dilemmas. Ataraxia in a limited fashion is to be found through skepticism, but no final, perpetual peace. Hume does not pretend to put an end to otherness, disagreement, and faction - certainly not in the proprietary and instrumental rationality of Lockean liberalism, or the idealized forms of communication of which Habermas fantasizes, or through simple but comforting conservative appeals to tradition. ${ }^{89}$ In this Hume anticipates something of Chantal Mouffe, who articulates a political theory of agonistic democracy. ${ }^{90}$

Hume's skepticism accepts and acknowledges the often unpleasant persistence of difference and faction; and he works to manage them just skeptically, through provisional agreements and rules of reflection that emerge from common life and can then be deployed in a critical engagement with custom among the participants in a contested political order. Hume holds no illusions about the inclination to division to which people are subject: "Men have such a propensity to divide into personal factions, that the smallest appearance of real difference will produce them" (ES 57); humankind has "a strong propensity to such divisions" (ES 58).

As it is in the sciences, the process for Hume of reflectively informing our political judgment and methodizing general rules used to correct other general rules is in this sense for Hume an open-ended one, an ongoing project. Hume's politics are for this reason skeptical not only because as a matter of zetesis they do not advance a single political ideal that Hume presumes can be achieved. Schleifer McCormick unwittingly pinpoints the Pyrrhonian zetesis of Hume's politics when she quotes J. G. A. Pocock, who writes: "The World of the Imagination would continue to require the discipline of classical criticism; the civilized monarchy ... would continue to require the discipline of republican freedom.... Hume held [both] that authority and liberty could never be reconciled and that neither could replace the other," at least never finally reconciled, a point Hume seems to affirm at ES 40-41. ${ }^{91}$ Even traditionalist Livingston acknowledges the zetetic quality of Hume's political thought when

\footnotetext{
${ }^{88}$ Loeb (2005), 9.

${ }^{89}$ Habermas (1985).

${ }^{90}$ Mouffe (2005), 3. Cf. Mouffe (1993).

91 McCormick (2013), 84. Pocock (1979), 335-36. Hume writes there, e.g.: "In all governments, there is a perpetual intestine struggle, open or secret, between AUTHORITY and LIBERTY; and neither of them can ever absolutely prevail in the contest" (ES 40).
} 
he writes that for Hume "tradition is dynamic and open ended." The ancient roots to Hume's practice, however, Livingston, Schleifer McCormick, Pocock and so many others have missed. ${ }^{93}$

\section{Conclusion}

Hume's political thought, then, is skeptical in a variety of ways. A politics of opinion and appearance, it deploys skeptical instruments to undermine political rationalism as well as theologically and metaphysically political ideologies. It labors to oppose faction and enthusiasm and to generate suspension, balance, tranquility, and moderation. Because of Hume's advocacy of the use of reflectively generated but epistemically and metaphysically suspensive general rules, Humean politics is not intrinsically conservative. While it valorizes stability and peace, Humean politics accepts a contested and open-ended political order, one that requires continuous maintenance and revision but does not pretend to any ultimate or final progress or end.

92 Livingston (1990), 134; cited by Susato (2015), 85.

93 Schleifer McCormick recognizes the openness of Hume's skeptical political philosophy without relating it to Pyrrhonism's zetetic practices. McCormick (2013), 81: "Humean skepticism would oppose whoever claims complete knowledge, whoever declares inquiry closed or forbids open discussion and freedom of thought. Given that the skeptic shuns dogma, it is unlikely that he would attach himself to a particular movement or party. It seems that on any particular question the skeptic would try his best to come to as clear and unprejudiced a view as possible and would, in consequence, agree with some parties on some questions and with other parties on other questions." About Hume and disagreement, cf. Garrett (2014), 127, 139, 144; cited by Loeb (2014), 244. 


\section{References:}

Adair, Douglass (1956/57). "“That Politics May Be Reduced to a Science': David Hume, James Madison, and the Tenth Federalist," Huntington Library Quarterly 20:343-60.

Baxter, Donald M. (2008). Hume's Difficulty: Time and Identity in the Treatise. London: Routledge.

Bongie, Laurence L. (2002). David Hume: Prophet of the Counter-Revolution, foreword by Donald W. Livingston. Indianapolis: Liberty Fund. Originally published by Oxford University Press, 1965.

Burke, Edmund (2009). Reflections on the Revolution in France. Oxford: Oxford University Press. Originally 1790.

Clark, Sam (2013). “Hume's Uses of Dialogue,” Hume Studies 39.1: 61-76. Cumming, Robert Denoon (1969). Human Nature and History: A Study of the Development of Liberal Political Thought, 2 vols. Chicago: University of Chicago Press.

Dees, Richard (2008). "“One of the Finest and Most Subtile Inventions': Hume on Government," 388-405 in A Companion to Hume, Elizabeth Radcliffe (ed.). Malden, MA: Blackwell Publishing. (2002). "Morality above Metaphysics: Friendship and Philo's Stance in Dialogues XII," Hume Studies 28: 131-47.

Deleuze, Gilles (1953). Empiricism and Subjectivity: An Essay on Hume's Theory of Human Nature, trans. C. V. Boundas. New York: Columbia University Press, 1991.

Eichorn, Roger (2014). "How (Not) to Read Sextus Empiricus," Ancient Philosophy 24: 121-49.

Forbes, Duncan (1978). "The European, or Cosmopolitan Dimension in Hume's Science of Politics," The British Journal for Eighteenth-Century Studies 1.1: 57-60.

(1975). Hume's Philosophical Politics. Cambridge: Cambridge University Press.

(1954). "Scientific' Whiggism: Adam Smith and John Millar," Cambridge Journal 6.2:280-323.

Garrett, Don (2014). Hume. Milton Park and New York: Routledge.

Habermas, Jürgen (1985). The Theory of Communicative Action, 2 vols. (Reason and the Rationalization of Society; Handlungsrationalität und gesellschaftliche Rationalisierung) and (Lifeworld and System: A Critique of Functionalist Reason; Zur Kritik der funktionalistischen Vernunft [1981]). Boston: Beacon Press. 
Harris, James A. (2015). David Hume: An Intellectual Biography. Cambridge: Cambridge University Press. (2007). Book review of Neil McArthur, David Hume's Political Theory: Law, Commerce, and the Constitution, in Hume Studies 33.2 (November): 335-38.

Hayek, F. A. (1966). "The Legal and Political Philosophy of David Hume," 335-60 in Hume: A Collection of Critical Essays, Vere Claiborne Chappell (ed.). South Bend: University of Notre Dame Press. Originally published in Il Politico 28 (1963).

Herdt, Jennifer (1997). Religion and Faction in Hume's Moral Philosophy. Cambridge: Cambridge University Press.

Hume, David (2007). A Treatise of Human Nature: A Critical Edition, David Fate Norton \& Mary J. Norton (eds.), 2 vols. Oxford: The Clarendon Press. Originally 1739-40. T.

(2000). Enquiry concerning Human Understanding: A Critical Edition, T. L. Beauchamp (ed.). Oxford: Clarendon Press, 2000. Originally, 1748. E.

(1998). Enquiry concerning the Principles of Morals, T. L. Beauchamp (ed.). Oxford: Clarendon Press. M.

(1985). Essays: Moral, Political, and Literary (with an apparatus of variant readings from the 1889 edition by T. H. Green and T. H. Grose), Eugene F. Miller (ed.) Indianapolis: Liberty Classics. Hume's essays first published as Essays: Moral and Political (Edinburgh: Alexander Kincaid, 1741, 2nd edition 1742, 3d edition 1748); Political Discourses (first \& second editions 1752, 3d edition, 1754); Essays and Treatises on Several Subjects (1753-77). ES.

(1983). The History of England: From the Invasion of Julius Caesar to the Revolution of 1688, in six volumes. Indianapolis: Liberty Fund. H.

(1947). Dialogues concerning Natural Religion, ed. N. Kemp Smith. New York: Bobbs Merrill. Originally 1779. D.

(1932). The Letters of David Hume, J. Y. T. Greig (ed.), 2 vols. Oxford: The Clarendon Press. Paperback 2011. LT.

(1889), Essays: Moral, Political, and Literary, T. H. Green and T. H.

Grose (eds.), New Edition. London: Longmans, Green, and Co.

Immerwahr, John (1994). "David Hume on Incompatible Religious Beliefs," International Studies in Philosophy 14 (1984), 25-33. Also reprinted in David Hume: Critical Assessments, ed. Stanley Tweyman (New York, Routledge, 1994). 
(1992). "Hume on Tranquilizing the Passions," Hume Studies 18:2 (1992), 293-314.

Laursen, John Christian (2016). "Natura vs. Libertà: The Moral Life of the Ancient Skeptics: Living in Accordance with Nature and Freedom from Disturbance," Bollenttino della Società Filosofica Italiana N.S. 219 (September/December): 5-21.

(2011). "David Hume on Custom and Habit and Living with Skepticism" ["David Hume: sobre la costumbre, el hábito y el vivir siendo un escéptico"]. Daimon: Revista Internacional de Filosofía 52:87-99.

(2010). "Tame Skeptics at the Prussian Academy," Libertinage et philosophie 12: 221-30.

Laursen, John Christian and Richard H. Popkin (1997). "Hume in the Prussian Academy: Jean Bernard Merian's 'On the Phenomenalism of David Hume," Hume Studies 23.1: 153-91.

Letwin, Shirley Robin (1965). The Pursuit of Certainty. Cambridge: Cambridge University Press. Reissued by the Liberty Fund (1998).

Livingston, Donald W. (1998), Philosophical Melancholy and Delirium: Hume's Pathology of Philosophy. Chicago: University of Chicago Press.

Livingston, Donald W. \& Marie A. Martin (eds.) (1991). Hume as Philosopher of Society, Politics, and History, Library of the History of Ideas 4. University of Rochester Press.

Livingston, Donald W. \& James T. King (eds.) (1976). Hume: A Re-Evaluation. New York: Fordham University Press.

Livingston, Donald W (1984). Hume's Philosophy of Common Life. Chicago: University of Chicago Press

Loeb, Louis (2005). Stability and Justification in Hume's Treatise. Oxford: Oxford University Press; in the UK 2002.

Lom, Petr (2001). The Limits of Doubt: The Moral and Political Implications of Skepticism. Albany: The State University of New York Press.

Martin, Marie A. (1994). "Hume as a Classical Moralist," International Philosophical Quarterly 24 (September): 323-34.

Mates, Benson (1996). The Skeptic Way: Sextus Empiricus's Outlines of Pyrrhonism. Oxford: Oxford University Press.

McArthur, Neil (2007). Hume's Political Theory. Toronto: University of Toronto Press.

McCormick, Miriam Schleifer (2013). "Hume's Skeptical Politics," Hume Studies 39.1: 77-102.

Merrill, Thomas W. (2015a). Hume and the Politics of Enlightenment. Cambridge: Cambridge University Press. 
(2015b). "Hume' Socratism," The Review of Politics 77: 23-45. (2005). "The Rhetoric of Rebellion in Hume's Constitutional Thought," The Review of Politics, 67.2: 257-82.

Mill, John Stuart (1838). "Bentham," in Essays on Ethics, Religion, and Society, 75-85 in vol.10 of the Collected Works of John Stuart Mill, 33 vols., J. M. Robson (ed.). Toronto: University of Toronto Press, 1963-91.

Miller, David (1981). Philosophy and Ideology in Hume's Political Thought. Oxford: Clarendon Press.

Mossner, Ernst Campbell (1941). "Was Hume a Tory Historian?” Journal of the History of Ideas 2: 225-36. Reprinted in Livingston \& Martin (1991), 106-17.

Mouffe, Chantal (2005). The Democratic Paradox. New York: Routledge.

(1993). The Return of the Political. New York: Verso, 1993.

Oakeshott, Michael (2010). Rationalism in Politics and Other Essays, an expanded edition. Indianapolis: Liberty Fund.

(1947). "Rationalism in Politics," Cambridge Journal 1: 65-74.

Pocock, J. G. A. (1979). "Hume and the American Revolution: The Dying Thoughts of a North Briton," 325-43 in McGill Hume Studies, David Fate Norton, Nicholas Capaldi, and Wade Robison (eds.). San Diego: Austin Hill Press.

Poole, Thomas (2015). Reason of State: Law, Prerogative and Empire. Cambridge: Cambridge University Press.

Resnick, David (1996). "David Hume: A Modern Conservative," The European Legacy 1.1: 397-402.

Sabl, Andrew (2015). "David Hume: Skepticism in Politics?” 149-176 in Skepticism and Political Thought in the Seventeenth and Eighteenth Centuries, John Christian Laursen and Gianni Paganini (eds.). Toronto: University of Toronto Press.

(2012). Hume's Politics: Coordination and Crisis in the History of England. Princeton: Princeton University Press.

Schmitt, Carl (1927). Der Begriff des Politischen. München and Leipzig: Duncker \& Humbolt. Translated in The Concept of the Political: Expanded Edition. George Schwab (trans.). Chicago: University of Chicago Press, 2008.

Sextus Empiricus (1976). Outlines of Pyrrhonism, in Sextus Empiricus, 1 of 4 vols. R. G. Bury (ed. and trans.), Loeb Classical Library. Cambridge: Harvard University Press. PH. 
(1968). Adversus Mathematicos $I X-X I$, R. G. Bury (trans.). Loeb Library III. Cambridge: Harvard University Press. M.

Spencer, Mark G. (2010). Hume and Eighteenth-Century America. Rochester: University of Rochester Press.

Stephen, Leslie (1949). History of English Thought in the Eighteenth Century, 3rd edition, vol. 2. New York: Peter Smith.

Stourzh, Gerald (1970). Alexander Hamilton and the Idea of Republican Government. Stanford: Stanford University Press.

Susato, Ryu (2015). Hume's Sceptical Enlightenment. Edinburgh: University of Edinburgh Press.

Werner, John M. (1972). “David Hume and America” The Journal of Philosophy 33.3: 439-56.

Whelan, Frederick G. (1985). Order and Artifice in Hume's Political Philosophy. Princeton: Princeton University Press.

Wiley, James (2012). Theory and Practice in the Philosophy of David Hume. Houndsmills: Palgrave Macmillan.

Wills, Gary (1981). Explaining America: The Federalists. New York: Doubleday. Wittgenstein, Ludwig (1972). On Certainty, G. E. M. Anscombe \& G. H. von Wright (eds.). New York: Harper Torchbook.

Wolin, Sheldon S. (1954). "Hume and Conservatism," The American Political Science Review 48.4: 999-1016. Reprinted in Livingston \& King (1976), 239-56.

Wright, John (1983). The Sceptical Realism of David Hume. Minneapolis: University of Minnesota Press.

Wulf, Steven J. (2000). “The Skeptical Life in Hume’s Political Thought,” Polity 33.1: 77-99. 
